\title{
Seasonality Analysis on High- and Low-Rainfall Regions in Bangladesh using Precipitation Concentration Index
}

\author{
Md. Anarul Haque Mondol ${ }^{1} \cdot$ Mehedi Iqbal $^{1} \cdot$ Al-Mamun $^{1,2} \cdot$ Dong-Ho Jang $^{2}$ \\ ${ }^{1}$ Department of Geography and Environment, Jahangirnagar University \\ ${ }^{2}$ Department of Geography, Kongju National University, Gongju
}

(Received 14 June 2017, Revised 24 June 2017, Accepted 26 June 2017)

\section{강수집중지수를 이용한 방글라데시의 다· 소우지역 강수의 계절성 분석}

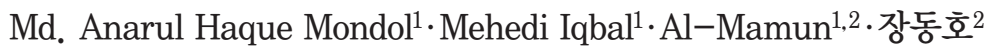 \\ ${ }^{1}$ Department of Geography and Environment, Jahangirnagar University·공주대학교 지리학과 \\ (2017년 6월 14일 접수, 2017년 6월 24일 수정, 2017년 6월 26일 게재 확정)
}

\begin{abstract}
It is difficult to measure precipitation due to spatial and temporal variability. In this study we analyzed the variability of precipitation of high- and low-rainfall regions in Bangladesh using Precipitation Concentration Index (PCI) from the data of two meteorological stations. We compared PCI values for various periods such as annual, supra-seasonal, seasonal, three and two-months. Most previous studies have analyzed the long-term precipitation in Bangladesh. We analyzed the variabilities from long-term to short-term and tried to characterize the irregular precipitation. In the result, the precipitation in Bangladesh was mostly concentrated between two and four months of the year. Future research will require more station data to understand the more detailed precipitation patterns in Bangladesh.
\end{abstract}

Key Words : Precipitation Concentration Index, monsoon, rainfall seasonality, Bangladesh 주요어 : 강수집중지수, 몬순, 강수계절성, 방글라데시

\section{Introduction}

The study of rainfall is inextricably linked to that of soil erosion because the former is a variable changing in of time and space (Apaydin et al., 2006). This variability makes precipitation is one of the most difficult atmospheric parameters to measure (Islam et al., 2005a). The amount and intensity of precipitation can influence soil erosion slope instability, plant growth and agricultural practices (Scholz et al., 2008; Coscarelli and Caloiero, 2012) as well as modify fluvial systems, groundwater recharge, water disposal and hydroelectric projects (Aguado et al., 1992; López-Moreno et al., 2009). Variations in rainfall

Correspondence: Dong-Ho Jang, Department of Geography, College of Social Science, Kongju National University, 56, Gongjudaehak-ro Gongju-Si, Chungcheongnam-do, 32588, Republic of Korea, Phone: +82-41-850-8421, Fax: +82-41-850-8425, E-mail: gisrs @kongju.ac.kr 
encourage opposing phenomena like drought and floods (Coscarelli and Caloiero, 2012) and modify the water cycle (Huntington, 2006; De Luis et al., 2011). Precipitation is increasingly important all over the world, both from climate perspective and also as a natural resource due to the combination of scarcity and high spatial and temporal variability (De Luis et al., 2011). A better understanding of the exact mechanisms for the conveyance and measurement of precipitation is thus helpful for disaster prediction and water administration (Islam et al., 2005b).

A precise understanding of the distribution and nature of precipitation is especially useful for disaster prevention and water management in a country like Bangladesh (Rafiuddin et al., 2010). Though many studies have been carried out on rainfall and temperature in general, research on the intensity and distribution of rainfall has hardly been done for this region (Iskander et al., 2014); most research has been done on an annual or six-month basis. One study (Iskander et al., 2014) based on the Precipitation Concentration Index (PCI) showed irregular precipitation distribution all across Bangladesh, especially in the southeast. Although there is no single research method that can comprehensively examine changes in precipitation over time, it is worth considering how different methods can be applied to certain situations (Rand, 2012). For example, some studies about precipitation variability focus on patterns in regions influenced by extreme precipitation events. Another aspect of precipitation change that is important in some applications relates to trends in the area affected by heavy or extreme precipitation amounts (Karl and Knight, 1998).

The climate of Bangladesh is becoming more unprecedented every year: the country will experience an increase in rainfall of $5 \%$ to $6 \%$ by 2030 (Iskan- der et al., 2014). There are several straightforward indicators for the evaluation of precipitation patterns that can be used to assess variability and analyze hydrological processes (De Luis et al., 2011). Among the different indices used for this purpose, the PCI (Oliver, 1980) is recommended since it provides information on long-term total variability in the amount of rainfall received (Michiels et al., 1992; De Luis et al., 2011).

Our study analyzed the PCI data in relation to high- and low-rainfall zones of Bangladesh at different time intervals to categorize the precipitation concentration patterns and evaluate the changes, uncertainties and seasonal variations of precipitation over a long period.

\section{Materials and methods}

\section{1) Study process}

We designed our study to identify the precipitation concentration changes at different time intervals on the basis of relatively high- and low-rainfall zones of Bangladesh. We obtained seasonal, supra-seasonal and annual precipitation data from the Bangladesh Metrological Department (BMD) for the period from 1977-2011 and used these as input data for the PCI.

We also used these data were to calculate a comparative correlation between the PCI values for the two-month and three-month intervals. We then tried to define uniform, moderately irregular and highly irregular precipitation periods as well as the seasonal effects of precipitation on the surrounding area. For spatial analysis of precipitation, we interpolated the weather stations onto a regular grid. The resulting data were used to analyze variations 
in precipitation concentration between the annual, seasonal, supra-seasonal, three- and two-month PCI values for the study area.

\section{2) Study area and data set}

Bangladesh is dominated by low-laying flat plains drained by the Padma and Brahmaputra Rivers; the Tropic of $\left(231^{\circ} \mathrm{N}\right)$ goes over the middle of the country. A subtropical monsoon climate is strongly active in this region which is also affected by tropical cyclones (Krishna, 2009). The country faces a vast amount of rainfall annually, especially during the monsoon (Ahmed et al., 2006). The world's most precipitation-prone location (Cherrapunji, in the
Indian state of Meghalaya) is just across the northern border. So, this region is comparatively rainfall dominated area. Precipitation concentration varies within the country: according to the Bangladesh Metrological Administration, the average annual precipitation varies from a maximum of $5,690 \mathrm{~mm}$ in the northeast to a minimum of $1,110 \mathrm{~mm}$ in the west (BMD). Bangladesh has 30 metrological observatories (Figure 1), but only two have rainfall data from 1977-2011: one in the high-rainfall area of Srimangal in the northeast (between $24^{\circ} 03^{\prime}$ to $24^{\circ} 15^{\prime} \mathrm{N}$ and $89^{\circ} 00^{\prime}$ to $89^{\circ} 11^{\prime} \mathrm{E}$ ) and one is the low-rainfall area of Ishurdi in the southwest (between $24^{\circ} 08^{\prime}$ to $24^{\circ} 28^{\prime} \mathrm{N}$ and $91^{\circ} 36^{\prime}$ to $91^{\circ} 48^{\prime}$ E) (banglapedia, 2003).

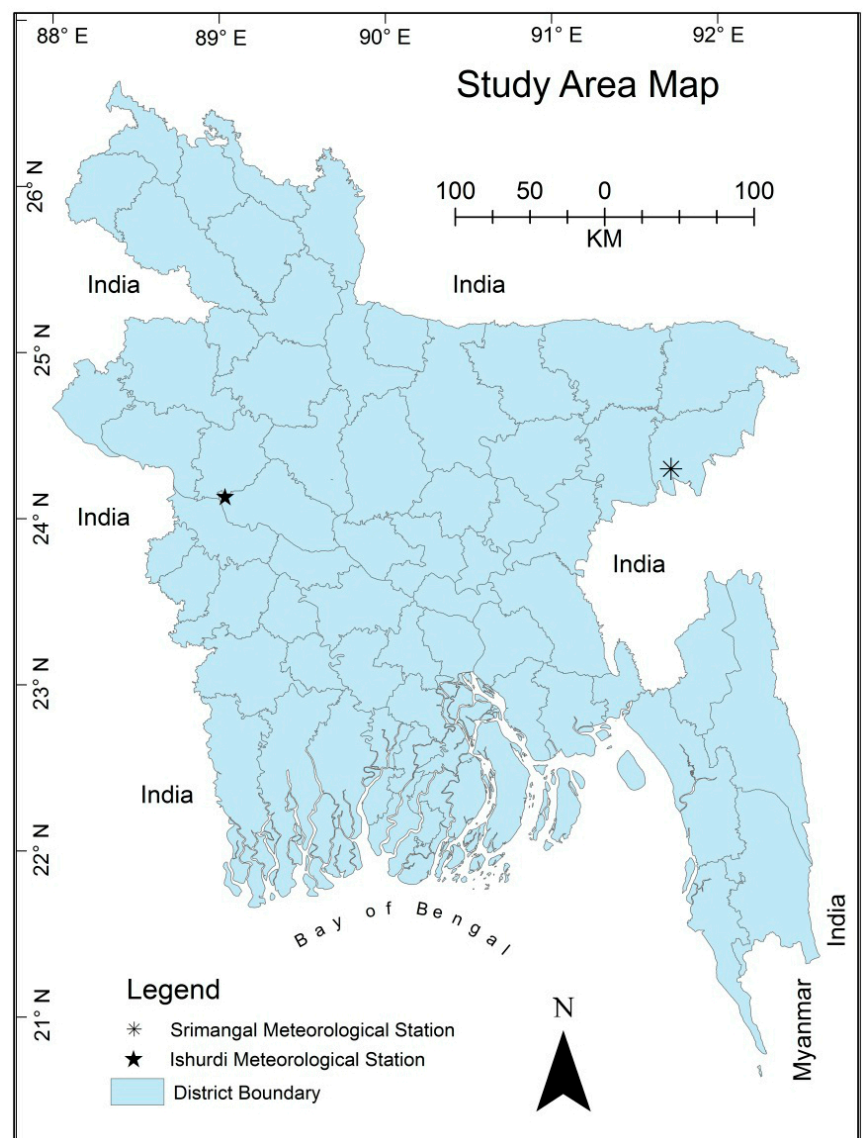

Figure 1. Map of Bangladesh showing meteorological stations, including Srimangal and Ishurdi. 


\section{3) $\mathrm{PCl}$ methods}

We calculated the PCI values using data from two stations based on the equations given by Oliver (1980). The Precipitation Concentration Index (PCI) (Oliver, 1980); this was done on an annual scale for each grid point according to Eq. (1):

$$
\mathrm{PCI}_{\text {annual }}=\frac{\sum_{i=1}^{12} P_{i}^{2}}{\left(\sum_{i=1}^{12} P_{i}\right)^{2}} \times 100
$$

Where, $P_{i}$ is the total precipitation in month. The PCI was also calculated on a supra-seasonal scale (Eq. (2)) from January to June (JJ) and July to December (JD) and on a seasonal scale (Eq. (3)) for winter (November to February, NDJF), summer or pre-monsoon (March to June, MAMJ) and monsoon (July to October, JASO).

$$
\begin{gathered}
\mathrm{PCI}_{\text {supra-seasonal }}=\frac{\sum_{i=1}^{6} P_{i}^{2}}{\left(\sum_{i=1}^{6} P_{i}\right)^{2}} \times 50 \\
\mathrm{PCI}_{\text {seasonal }}=\frac{\sum_{i=1}^{4} P_{i}^{2}}{\left(\sum_{i=1}^{4} P_{i}\right)^{2}} \times 33.3333
\end{gathered}
$$

We are calculated three- and two-month PCI intervals (Eq. (4) and (5), respectively) to break down the annual, seasonal and supra-seasonal precipitation distribution and concentration.

$$
\begin{aligned}
\mathrm{PCI}_{\text {three month interval }} & =\frac{\sum_{i=1}^{3} P_{i}^{2}}{\left(\sum_{i=1}^{3} P_{i}\right)^{2}} \times 25 \\
\mathrm{PCI}_{\mathrm{two} \text { month interval }} & =\frac{\sum_{i=1}^{2} P_{i}^{2}}{\left(\sum_{i=1}^{2} P_{i}\right)^{2}} \times 16.67
\end{aligned}
$$

As defined by Oliver (1980), PCI values of less than 10 represent a uniform precipitation distribution (i.e., low precipitation concentration), PCI values from 11 to 15 denote a moderate precipitation concentration, values from 16 to 20 denote irregular distribution, and values above 20 represent a strong irregularity (i.e., high precipitation concentration).
According to our analysis of the PCI formulae, on the annual, seasonal and supra-seasonal scales a PCI value less than 10 indicates perfect uniformity of precipitation distribution (the same or nearly similar amount of rainfall occurred in each month). On all scales, a PCI value of 16 to 20 indicates that the total precipitation was concentrated in half of the period and a PCI value greater than 20 indicates that the total precipitation was concentrated in one-third of the period. For example, this last value indicates that most annual precipitation occurred within 4 months, most supra-seasonal precipitation occurred within 2 months and most seasonal precipitation occurred within one month. In other words, intensive rainfall can be considered uniform if it occurs throughout the time period, but if it occurs within a narrow subset of the time period, then its distribution is considered irregular.

\section{Results}

\section{1) Annual $\mathrm{PCl}$}

Annual precipitation distribution was not uniform in any year of the study period, while moderate precipitation distribution occurred in seven years at Ishurdi and fourteen years at Srimangal (Table 1 and 2, Figure 2). Strong irregularities occurred more frequently at the Ishurdi station (6) as compared to the Srimangal station (2), while irregular precipitation also occured more frequently at Ishurdi (22 years vs. 19 at Srimangal). This analysis indicates that annual precipitation concentration is similar in both locations, as most values for both locations fell in the same category. 


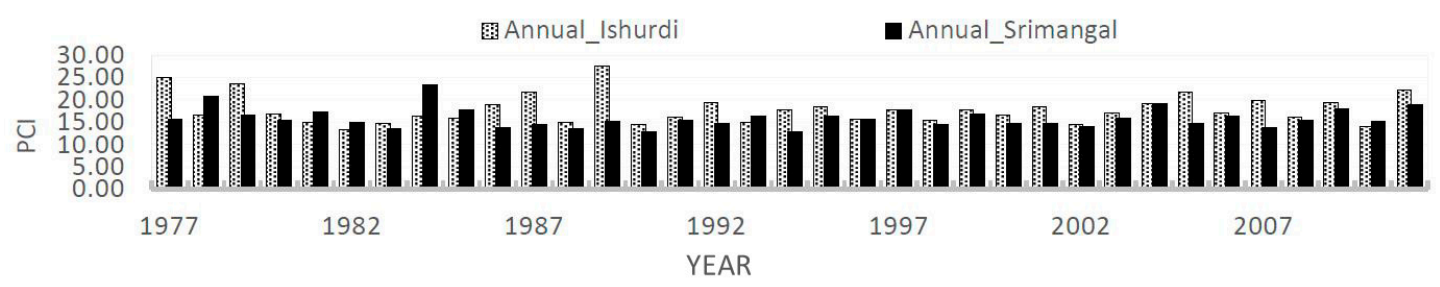

Figure 2. Annual Precipitation Concentration Index (PCl) values for Ishurdi and Srimangal meteorological stations.

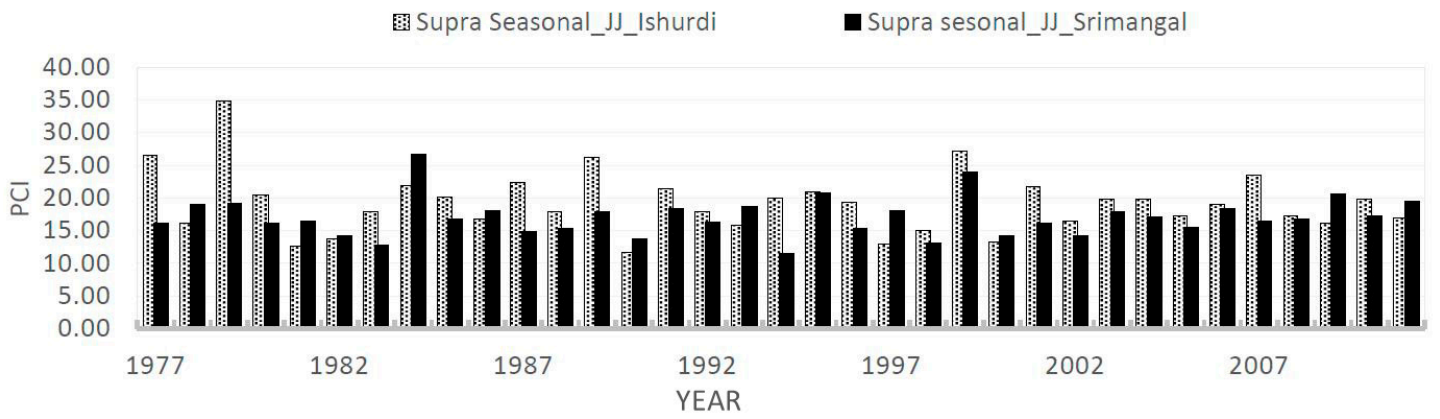

Figure 3. Supra-seasonal Precipitation Concentration Index (PCl) values for Ishurdi and Srimangal meteorological stations.

\section{2) Supra-seasonal PCI}

The first-half of the year (JJ) had stronger PCI anomalies than the second half (JD) (Table 1 and 2, Figure 3). Strong irregularities occurred in four years at Srimangal and in twelve years at Ishurdi. The JD period recorded a higher number of moderate concentrations than the JJ period for both sites, through the opposite was true for irregular concentrations. Twenty seven moderate, seven irregular, and one strong irregular precipitation concentrations were found at Srimangal (Table 1) and twenty moderate, fourteen irregular and one strong irregular precipitation concentrations were found in the supra-seasonal analysis at Ishurdi (Table 2).

\section{3) Seasonal PCI}

There are three main seasons in Bangladesh; the pre-monsoon or summer, the monsoon or rainy season and the post-monsoon or winter. Normally the pre-monsoon and post-monsoon seasons have little rainfall; on average $80 \%$ or more of the country's annual rainfall is received during the monsoon season. Our analysis of the seasonal PCI found that strong irregularities (at both sites) were most common during NDJF, moderate irregularities were most common in MAMJ, and precipitation was least irregular in JASO (Table 1 and 2, Figure 4). Only twelve years of near uniform precipitation concentration was found in the MAMJ period. The JASO period had twenty-four years of uniform precipitation concentration.

Our analysis shows that at Srimangal, there were one uniform, three moderate, fifteen irregular and sixteen strong irregular precipitation concentration 
Table 1. PCl values and categories for different time intervals; data from the Srimangal meteorological station.

\begin{tabular}{|c|c|c|c|c|}
\hline Time Interval & $\begin{array}{l}\text { Uniform precipitation } \\
\text { distribution }(<10)\end{array}$ & $\begin{array}{l}\text { Moderate precipitation } \\
\text { distribution (11 to } 16 \text { ) }\end{array}$ & $\begin{array}{c}\text { Irregular distribution } \\
\quad(16 \text { to } 20)\end{array}$ & $\begin{array}{c}\text { Strong irregularity of } \\
\text { precipitation distribution }(>20)\end{array}$ \\
\hline Annual & 0 & 14 & 19 & 2 \\
\hline Supra-Seasonal_JJ & 0 & 8 & 23 & 4 \\
\hline Supra-Seasonal_JD & 0 & 27 & 7 & 1 \\
\hline NDJF & 1 & 3 & 15 & 16 \\
\hline MAMJ & 5 & 28 & 2 & 0 \\
\hline JASO & 21 & 14 & 0 & 0 \\
\hline JFM & 3 & 14 & 8 & 10 \\
\hline AMJ & 19 & 16 & 0 & 0 \\
\hline JAS & 31 & 4 & 0 & 0 \\
\hline OND & 0 & 14 & 6 & 15 \\
\hline $\mathrm{JF}$ & 6 & 8 & 18 & 0 \\
\hline FM & 11 & 15 & 9 & 0 \\
\hline MA & 14 & 17 & 4 & 0 \\
\hline $\mathrm{AM}$ & 20 & 14 & 1 & 0 \\
\hline MJ & 33 & 2 & 0 & 0 \\
\hline JJ & 32 & 3 & 0 & 0 \\
\hline JA & 30 & 5 & 0 & 0 \\
\hline AS & 33 & 2 & 0 & 0 \\
\hline SO & 25 & 10 & 0 & 0 \\
\hline ON & 8 & 10 & 17 & 0 \\
\hline ND & 2 & 8 & 20 & 0 \\
\hline DJ & 2 & 3 & 22 & 0 \\
\hline
\end{tabular}

years in the NDJF period; five uniform, twentyeight moderate, and two irregular precipitation concentration years in the MAMJ period; twentyone uniforms, and fourteen moderate precipitation concentration years in the JASO period (Table 1). At Ishurdi there were two uniform, four moderate, ten irregular and eighteen strong irregular precipitations concentration years in the NDJF period; two uniform, twenty three moderate, eight irregular and two strong irregular precipitation concentration years in the MAMJ period; and sixteen uniform and nineteen moderate precipitation concentration years in the JASO period (Table 2).

\section{4) Three Month $\mathrm{PCl}$}

Of the three-month study periods, JAS had the highest number of uniform precipitation concentrations at either site (Table 1 and 2, Figure 5). Strong irregularities were found primarily in the JFM and OND periods, which are the dry periods in Bangladesh when little or no rainfall occurs, reflecting the irregularities seen in the PCI. The AMJ period is the pre-monsoon, which normally has moderate rainfall in the months of May and June increasing from April. The early rainfall of this period can sometimes bring flood to the country.

Our analysis indicates that the AMJ period in Srimangal had uniform precipitation concentration 
Table 2. PCI values and categories for different time intervals; data from the Ishurdi meteorological station.

\begin{tabular}{|c|c|c|c|c|}
\hline Time Interval & $\begin{array}{l}\text { Uniform precipitation } \\
\text { distribution }(>10)\end{array}$ & $\begin{array}{l}\text { Moderate precipitation } \\
\text { distribution (11 to 16) }\end{array}$ & $\begin{array}{l}\text { Irregular distribution } \\
\qquad(16 \text { to } 20)\end{array}$ & $\begin{array}{c}\text { Strong irregularity of } \\
\text { precipitation distribution }(>20)\end{array}$ \\
\hline PCI_annual & 0 & 7 & 22 & 6 \\
\hline Supra-Seasonal_JJ & 0 & 5 & 18 & 12 \\
\hline Supra-seasonal_JD & 0 & 20 & 14 & 1 \\
\hline NDJF & 2 & 4 & 10 & 18 \\
\hline MAMJ & 2 & 23 & 8 & 2 \\
\hline JASO & 16 & 19 & 0 & 0 \\
\hline JFM & 4 & 12 & 7 & 10 \\
\hline AMJ & 11 & 21 & 2 & 1 \\
\hline JAS & 32 & 3 & 0 & 0 \\
\hline OND & 0 & 11 & 6 & 18 \\
\hline JF & 4 & 12 & 13 & 0 \\
\hline FM & 9 & 11 & 12 & 0 \\
\hline MA & 13 & 12 & 10 & 0 \\
\hline $\mathrm{AM}$ & 19 & 12 & 4 & 0 \\
\hline MJ & 27 & 7 & 1 & 0 \\
\hline JJ & 27 & 8 & 0 & 0 \\
\hline JA & 34 & 1 & 0 & 0 \\
\hline AS & 29 & 6 & 0 & 0 \\
\hline SO & 14 & 16 & 5 & 0 \\
\hline ON & 5 & 10 & 19 & 0 \\
\hline ND & 2 & 2 & 21 & 0 \\
\hline DJ & 3 & 4 & 19 & 0 \\
\hline
\end{tabular}

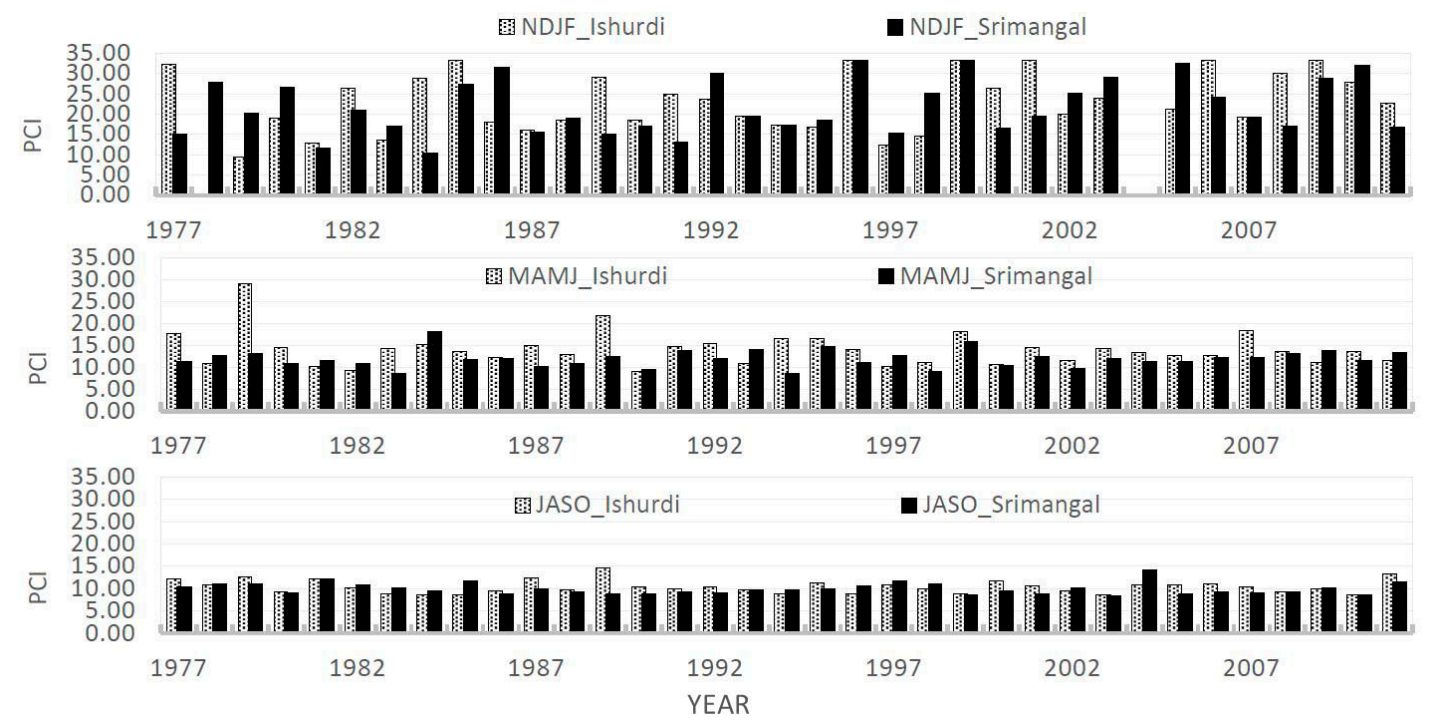

Figure 4. Seasonal Precipitation Concentration Index (PCl) values for Ishurdi and Srimangal meteorological stations. 
in nineteen years and moderate precipitation concentration in sixteen years whereas Ishurdi had uniform precipitation concentration in eleven years, moderate precipitation concentration in twenty-one years, irregular precipitation concentration in two years and strong irregularity in one year. In Srimangal the JFM and OND periods had irregular precipitation in eight and six years respectively and strong irregularities in ten and fifteen years respectively. On the other hand, in Ishurdi JFM and OND had irregular precipitation in seven and six years respectively and strong irregularities in ten and eighteen years respectively. JAS is the main monsoon period of the country, producing high rainfall which has a greater impact on agriculture and plants. The JAS period had the highest number of uniform precipita- tion concentrations with only four and three years of moderate precipitation found at Srimangal and Ishurdi respectively.

\section{5) Two month PCl}

Our analysis shows that most two-month periods had relatively uniform precipitation distributions; there were no strong irregularities recorded for any period or site (Table 1 and 2, Figure 6). Moderate and uniform rainfall was distributed relatively even in FM, MA and AM, while MJ, JJ, JA, and AS were especially uniform and ON, ND, DJ and JF had more irregular distributions than the rest. Our analysis shows that rainfall concentrations were most heterogeneous in non-rainfall seasons (JF, FM, MA, $\mathrm{AM}, \mathrm{ND}$, and DJ) and also in the transition period

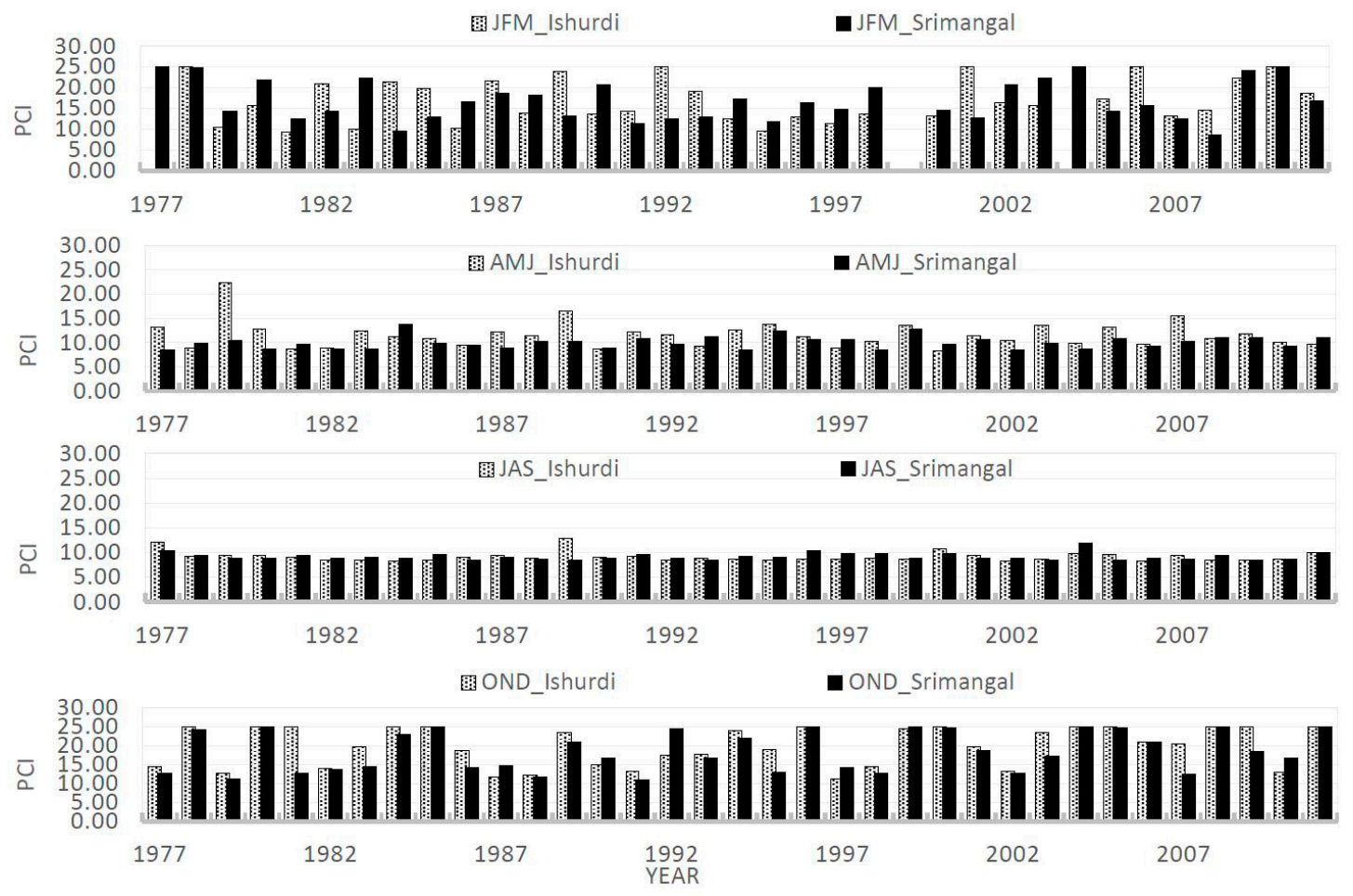

Figure 5. Three-month Precipitation Concentration Index (PCl) values for Ishurdi and Srimangal meteorological stations. 


\section{Two Month PCI Status}
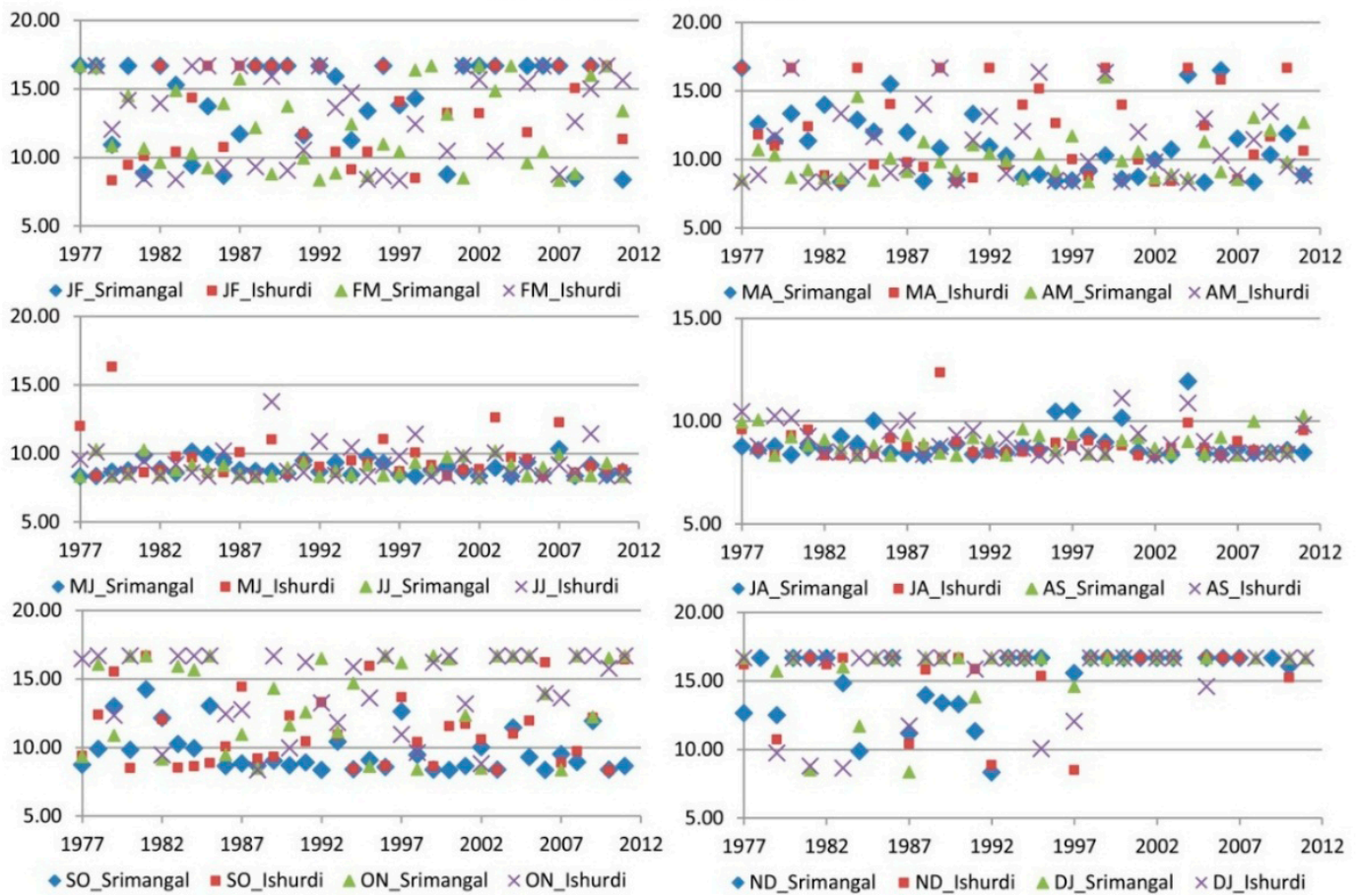

Figure 6. Two-month Precipitation Concentration Index (PCl) values for Ishurdi and Srimangal meteorological stations.

before and after the monsoon. During the monsoon season, despite precipitation being the most regular, more anomalies were found at Ishurdi than at Srimangal. Although these results mostly reflect normal rainfall characteristics of Bangladesh, some of the anomalies are of concern, requiring further study including investigating the relationship with other data from different meteorological stations within the country.

\section{Discussions}

Annual rainfall had irregular PCI distribution, while precipitation in the first half of the year was more irregular than the second half. Seasonal pre- cipitation was more uniform in JASO (the monsoon) than in other seasons, while NDJF had many more irregularities than MAMJ. This analysis indicates that longer periods of time produce higher PCI irregularities. Some PCI anomalies occurred in the study area. In short-term periods, precipitation was mainly characterized by seasons. Only a few years in winter had uniform rainfall distribution, meaning that the dry period had PCI anomalies of concern. The two-month periods AM, MJ, JJ, JA, AS, and $S O$ had the most uniform precipitation distribution though irregularities were found in many years. Most of the two-month winter periods had irregular distributions but the transition period from winter to pre-monsoon (MA) had moderate and uniform distribution in this period for all years and especially 
Table 3. Correlation of $\mathrm{PCl}$ values between the Ishurdi and Srimangal meteorological stations.

\begin{tabular}{l|c|l|c}
\hline \hline \multicolumn{1}{c|}{ Period } & r & \multicolumn{1}{c|}{ Period } & r \\
\hline Annual & 0.06 & FM & 0.08 \\
6 month_JJ & 0.35 & MA & 0.41 \\
6 month_JD & 0.26 & AM & 0.27 \\
NDJF & 0.28 & MJ & 0.06 \\
MAMJ & 0.24 & JJ & 0.01 \\
JASO & 0.22 & JA & 0.16 \\
JFM & 0.12 & AS & 0.24 \\
AMJ & 0.17 & SO & 0.29 \\
JAS & 0.24 & ON & 0.71 \\
OND & 0.77 & ND & 0.61 \\
JF & 0.40 & DJ & 0.49 \\
\hline \hline
\end{tabular}

Table 4. Statistical significance of PCl-value correlations between the Ishurdi and Srimangal meteorological stations.

\begin{tabular}{l|c|l|c}
\hline \hline \multicolumn{1}{c|}{ Period } & P Value & \multicolumn{1}{c|}{ Period } & P Value \\
\hline Annual & 0.010543 & FM & 0.252955 \\
6 month_JJ & 0.053950 & MA & 0.085951 \\
6 month_JD & 0.206669 & AM & 0.183133 \\
NDJF & 0.605168 & MJ & 0.052068 \\
MAMJ & 0.013461 & JJ & 0.203842 \\
JASO & 0.280578 & JA & 0.727392 \\
JFM & 0.677554 & AS & 0.544790 \\
AMJ & 0.006514 & SO & 0.006387 \\
JAS & 0.965251 & ON & 0.358131 \\
OND & 0.281649 & ND & 0.742989 \\
JF & 0.818679 & DJ & 0.606382 \\
\hline \hline
\end{tabular}

during winter.

Variations in rainfall were strongly linked with seasons over the study period. Intensive rainfall can be uniform if it occurs throughout the time period, but if it occurs within a shorter portion of the time period then its distribution can be called irregular; this effect was found in both regions. There were also strong variations in PCI values and the number of occurrences of precipitation concentration catego- ries between the Srimangal and Ishurdi sites. At all scales, a PCI value of 16 to 20 indicates that the total precipitation was concentrated in half of the period while a PCI value of more than 20 indicates that the total precipitation was concentrated in one-third of the period. Our analysis indicates that annual precipitation occurred mainly in four-month JASO period, supra-seasonal precipitation occurred mainly in two-month JJ and JA periods, and seasonal precipitation occurred mainly in the one-month periods of February for NDJF, June for MAMJ, and July for JASO.

We calculated correlations between the data for each study site; a positive correlation value indicates that both variables moved in the same direction. Most cases found low positive $r$ value, meaning low positive relationships between the variables. A weak positive linear relationship characterized most of the time periods except OND, ON, ND, and DJ, where a moderate positive liner relationship existed (Table 3).

Significant differences in the PCI index between Srimangal and Ishurdi occurred at many scales (Table 4). During supra-season period, we found that the first-half year significantly indicates precipitation changes in summer and winter. For the seasonal periods, we found significant differences in the premonsoon period of MAMJ. For three and twomonth periods, we found significant differences in AMJ, MA, MJ, and SO.

\section{Conclusions and Future Research}

Bangladesh is located in a monsoon climatic zone. The rainfall distribution in spatial and temporal 
unit of Bangladesh is not only uniform but also the monsoon precipitation is near to the uniformity. At an annual scale neither study site reported uniform precipitation distribution. Half of the periods had irregular precipitation concentration. Although there were some differences in precipitation concentration at the annual scale, in most cases these values were similar to those in the supra-seasonal periods. The first-half of the year period (JJ) had stronger anomalies than the second half (JD). PCI anomalies occurred at both study sites. In short-term periods, precipitation was characterized mainly by seasons. The two-month periods AM, MJ, JJ, JA, AS, and SOhad the maximum uniform precipitation distribution though irregularities were found in many years. We therefore recommend a more detailed analysis at the country level, as our analysis indicates that the two stations have poor positive correlation with moderate positive correlation found only in winter seasons.

The calculation of rainfall data is problematic as it is not possible to calculate PCI with zero rainfall and thus further analysis was impossible; if this were possible, output results would be more certain. Under the circumstances, our methods showed satisfactory results, but further study is needed to diagnose the relationship between PCI and the occurrence of extreme events such as soil erosion, drought and floods.

\section{Acknowledgement}

This work was supported by the Ministry of Education of the Republic of Korea and the National Research Foundation of Korea (NRF-2016S1A3A2924 243).

\section{References}

Aguado, E., Cayan, D., Riddle, L., and Roos, M., 1992, Climatic fluctuations and the timing of West Coast streamflow, Journal of Climate, 5(12), 1468-1483.

Ahmed, S., Isaac, R. H., Curtis, S., and Matsumoto, J., 2006, Teleconnections between the sea surface temperature in the Bay of Bengal and monsoon rainfall in Bangladesh, Global and Planetory Change, 53(3), 188-197.

Apaydin, H., Erpul, G., Bayranmin, I., and Gabriels, D., 2006, Evaluation of indices for characterizing the distribution and concentration of precipitation: A case for the region of Southeastern Anatolia Project, Turkey, Journal of Hydrology, 328 (3-4), 726-732.

Coscarelli, R. and Caloiero, T., 2012, Analysis of daily and monthly rainfall concentration in Southern Italy (Calabria region), Journal of Hydrology, 416417, 145-156.

De Luis, M. J., Gonzalez-Hidalgo, J. C., Brunetti, M. and Longares, L. A., 2011, Precipitation concentration changes in Spain 1946-2005, Natural Hazards and Earth System Science, 11(5), 1259. 1265.

Huntington, T. G., 2006, Evidence for intensification of the global water cycle: review and synthesis, Journal of Hydrology, 319(1), 83-95.

Iskander, S., Rajib, M. A., and Rahman, M., 2014, Trending regional precipitation distribution and intensity: Use of climatic indices, Atmospheric climate Sciences, 4(3), 385-393.

Islam, M. N., Hayashi, T., Terao, T., Uyeda, H., and Kikuchi, K., 2005b, Characteristics of precipitation systems analyzed from radar data over Bangladesh, Journal of Natural Disaster Science, 27(1), $17-23$.

Islam, M. N., Terao, T., Uyeda, H., Hayashi, T., and Kikuchi, K., 2005a, Spatial and temporal varia- 
tions of precipitation in and around Bangladesh, Journal of Meterological Society of Japan, 83(1), 21-39.

Karl, T. R. and Knight, R. W., 1998, Secular trends of precipitation amount, frequency, and intensity in the United States, Buletin of the American Meteorological Society, 79(2), 231-241.

Krishna, K. M., 2009, Intensifying tropical cyclones over the North Indian Ocean during summer monsoon, Global and Planetary Change, 65(1-2), 1216.

López-Moreno, J. I., Vicente-Serrano, S. M., Gimeno, L., and Nieto, R., 2009, Stability of the seasonal distribution of precipitation in the Mediterranean region: Observations since 1950 and projections for the 21st century, Geophysical Research Letters, 36(10), L10703.

Michiels, P., Gabriels, D., and Hartmann, R., 1992, Using the seasonal and temporal precipitation concentration index for characterizing the monthly rainfall distribution in Spain, Catena, 19(1), 43-
58.

Oliver, J. E., 1980, Monthly precipitation distribution: a comparative index, The Professional Geographer, 32(3), 300-309.

Rafiuddin, M., Uyeda, H., and Islam, M. N., 2010, Characteristics of monsoon precipitation systems in and around Bangladesh, International Journal of Climatology, 30(7), 1042-1055.

Rand, W. M., 2012, Objective criteria for the evaluation of clustering methods, Journal of American Statistical Association, 66(336), 846-850.

Scholz, G., Quinton, J. N., and Strauss, P., 2008, Soil erosion from sugar beet in Central Europe in response to climate change induced seasonal precipitation variations, Catena, 72(1), 91-105.

http://en.banglapedia.org/

http://www.bmd.gov.bd/ 